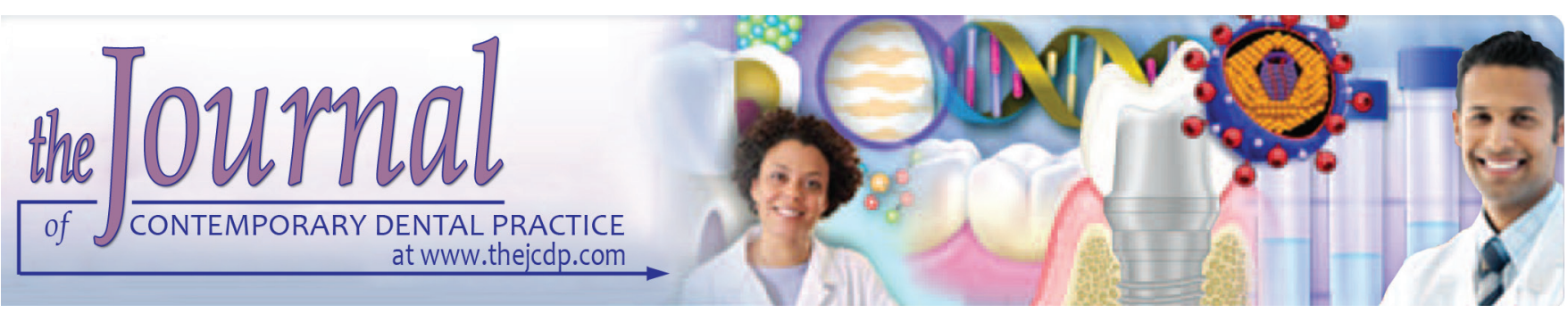

\title{
Patients' Awareness toward Implant-supported Prosthesis: An Observational Study
}

\author{
${ }^{1} \mathrm{C}$ Mahendra Raju, ${ }^{2}$ Sumanth Gunupati, ${ }^{3}$ Madisetty Mahesh Babu, ${ }^{4} \mathrm{C}$ Sameer Kumar Reddy \\ ${ }^{5}$ Sukrutha Biradavolu, ${ }^{6} \mathrm{M}$ Saravanan
}

\begin{abstract}
Introduction: Implant-supported prosthesis has high predictability and success and improves quality of life. This study aims at assessing awareness among the patients regarding implantsupported prosthesis.
\end{abstract}

Materials and methods: A cross-sectional study was conducted among 391 study participants. A structured questionnaire was distributed to assess implant-related awareness among the study participants. The questionnaires were analyzed for the responses.

Results: Among the 391 respondents, $37.5 \%$ of the respondents reported having moderate knowledge regarding the tooth replacement options. Nearly $50 \%$ considered implants as a viable treatment option. The majority of them enlisted the dentist as the major source of information regarding implants, and media had a share of about $7.03 \%$ only. High cost was a major barrier in selecting implants as a treatment option.

Conclusion: This survey showed that awareness among people was low regarding the dental implants. Efforts need to be directed to increase the awareness levels by utilizing media as a tool to achieve the target.

Clinical significance: A patient who is aware of the advantages of the implant-supported dentures will make an informed decision for better functional stability and retention of the denture, especially in the mandibular arch.

Keywords: Awareness, Implant-supported prosthesis, Knowledge. How to cite this article: Raju CM, Gunupati S, Babu MM, Reddy CSK, Biradavolu S, Saravanan M. Patients' Awareness

\footnotetext{
1,2,5 Department of Periodontology, Narayana Dental College \& Hospital, Nellore, Andhra Pradesh, India

${ }^{3}$ Department of Prosthodontics, Meghna Institute of Dental Sciences, Nizamabad, Telangana, India

${ }^{4}$ Department of Prosthodontics, Priyadarshini Dental College \& Hospital, Tiruvallur District, Tamil Nadu, India

${ }^{6}$ Department of Prosthodontics, SRM Dental College, Ramapuram Tamil Nadu, India

Corresponding Author: Sumanth Gunupati, Department of Periodontology, Narayana Dental College \& Hospital Chinthareddy Palem, Nellore, Andhra Pradesh, India, e-mail: sumant29@gmail.com; periosumant@hotmail.com
}

toward Implant-supported Prosthesis: An Observational Study. J Contemp Dent Pract 2017;18(1):49-51.

Source of support: Nil

Conflicts of interest: None

\section{INTRODUCTION}

Implant dentistry mainly deals with the replacement of lost teeth or congenitally missing teeth with artificial prosthesis, which mimics a natural root. The prosthesis can be used for single tooth replacement, for supporting complete denture, or even for obturators used in maxillectomy patients. Such prosthesis has the advantage of better associated quality of life and improved function of the patient. ${ }^{1-3}$ High predictability and success rates have increased the associated clinical implications of this treatment modality. ${ }^{1,4}$

Assessing the awareness of the people regarding implants helps in predicting better the felt need of the patients. Various studies have reported the awareness levels in different populations ranging from 42 to $79 \%{ }^{4-9}$ Recently, implant therapy has gained popularity and, hence, it is vital to assess the awareness levels among populations, so as to help them make informed decisions. Undergoing implant therapy has been reported to be a positive experience among many people and has improved their quality of life. ., $^{8}$

Implant therapy can be offered among patients with severely compromised local host bone, and it offers them improved phonetics and esthetics with good prognosis. ${ }^{10,11}$ Thus, the aim of this study was to assess the awareness levels among the patients regarding implantsupported prosthesis.

\section{MATERIALS AND METHODS}

A cross-sectional survey was conducted among the patients attending a dental outreach setting of the dental school. Random sampling technique was used to select the study 
participants, and a convenience sample of 400 study participants was used for the study. Consent was obtained from all the willing participants, and all of them were given a chance of refusal from participation. Ethical approval was obtained from the Institutional Ethics Committee prior to the start of the study.

A questionnaire was administered to all the willing participants in the local language. The questionnaire was adapted from the study of Kohli et al. ${ }^{7}$ All the responses were entered in an Excel sheet, and the descriptive statistics was calculated using Statistical Package for the Social Sciences version 17 .

\section{RESULTS}

Among the 400 patients who were approached for the study participation, 9 refused to participate; so, the final sample was 391. The sample included 173 females and 218 males. Of the total responses retrieved, none of the participants had undergone implant therapy. Nearly $47.8 \%$ of respondents belonged to age group of 16 to 40 years and $31.7 \%$ belonged to the age group of 41 to 60 years.

About $60 \%$ of the respondents had completed high school. Nearly $68 \%$ of the respondents reported one or more missing teeth (Table 1).

None of the respondents had undergone implant therapy. Nearly $37.5 \%$ of the respondents reported having moderate knowledge and 50\% reported having poor knowledge of available options of teeth replacement. Only 50\% of the respondents were aware of implants as a treatment option. The dentist was reported to be the major source of implant-related knowledge and media was a source of information for $7.03 \%$ of the respondents (Table 2).

Nearly $91 \%$ of the respondents reported that they "would like to get more information regarding dental implants." More than two-thirds of the respondents felt that the dentist would be a reliable source of information.

Table1: Demographic and clinical characteristics of the study participants

\begin{tabular}{llll}
\hline Variables & & $\begin{array}{l}\text { Study } \\
\text { participants }(n)\end{array}$ & $\begin{array}{l}\text { Total } \\
\text { sample }(n)\end{array}$ \\
\hline Gender & Males & 218 & 391 \\
& Females & 173 & \\
Age (years) & $16-40$ & 187 & 391 \\
& $41-60$ & 124 & \\
& 61 and above & 80 & 391 \\
Education & High school & 237 & \\
& College/graduation & 126 & \\
& University/ & 28 & \\
& $\begin{array}{l}\text { postgraduation and } \\
\text { above }\end{array}$ & & 391 \\
Presence & No missing teeth & 123 & \\
of missing & One or more missing & 268 & \\
teeth & teeth & & \\
\hline
\end{tabular}

Table 2: Distribution of study respondents for various study questions

\begin{tabular}{|c|c|c|c|}
\hline Variables & & $\begin{array}{l}\text { Study } \\
\text { participants } \\
\text { (n) }\end{array}$ & $\begin{array}{l}\text { Total } \\
\text { sample } \\
\text { (n) }\end{array}$ \\
\hline \multirow{2}{*}{$\begin{array}{l}\text { Have you had } \\
\text { dental implant } \\
\text { treatment before? }\end{array}$} & Yes & 0 & \multirow[t]{2}{*}{391} \\
\hline & No & 391 & \\
\hline \multirow{5}{*}{$\begin{array}{l}\text { How well do you } \\
\text { subjectively feel } \\
\text { informed about } \\
\text { alternatives of } \\
\text { replacing teeth? }\end{array}$} & Very well & 13 & \multirow[t]{5}{*}{391} \\
\hline & Well & 36 & \\
\hline & Moderately well & 147 & \\
\hline & Poor & 196 & \\
\hline & No answer & - & \\
\hline \multirow{5}{*}{$\begin{array}{l}\text { Are you aware of } \\
\text { the alternatives } \\
\text { for missing teeth } \\
\text { replacement? }\end{array}$} & $\begin{array}{l}\text { Implant-supported } \\
\text { dentures/bridges }\end{array}$ & 199 & \multirow[t]{5}{*}{391} \\
\hline & Partial dentures & 387 & \\
\hline & Complete dentures & 389 & \\
\hline & Bridges & 387 & \\
\hline & None of the above & 3 & \\
\hline \multirow{5}{*}{$\begin{array}{l}\text { Source of } \\
\text { information } \\
\text { regarding dental } \\
\text { implants }\end{array}$} & Television/radio & 14 & \multirow[t]{5}{*}{199} \\
\hline & Internet & 28 & \\
\hline & Dentist & 99 & \\
\hline & Relatives/friends & 22 & \\
\hline & $\begin{array}{l}\text { Someone who has } \\
\text { received an implant }\end{array}$ & 36 & \\
\hline
\end{tabular}

Table 3: Distribution of study respondents for various study questions

\begin{tabular}{|c|c|c|c|}
\hline Variables & & $\begin{array}{l}\text { Study } \\
\text { participants } \\
\text { (n) }\end{array}$ & $\begin{array}{l}\text { Total } \\
\text { sample } \\
\text { (n) }\end{array}$ \\
\hline \multirow{2}{*}{$\begin{array}{l}\text { Would you like to } \\
\text { get more information } \\
\text { regarding dental } \\
\text { implants? }\end{array}$} & Yes & 356 & 391 \\
\hline & No & 35 & \\
\hline \multirow{5}{*}{$\begin{array}{l}\text { From where would } \\
\text { you like to get } \\
\text { information about } \\
\text { dental implants? }\end{array}$} & Television/radio & 50 & \\
\hline & Internet & 59 & \\
\hline & Dentist & 302 & \\
\hline & Relatives/friends & 42 & \\
\hline & $\begin{array}{l}\text { Someone who } \\
\text { received an implant }\end{array}$ & 38 & \\
\hline \multirow{3}{*}{$\begin{array}{l}\text { What do you think } \\
\text { are the advantages } \\
\text { of nonremovable } \\
\text { versus removable } \\
\text { dentures? }\end{array}$} & $\begin{array}{l}\text { More comfortable } \\
\text { in the mouth }\end{array}$ & 364 & \\
\hline & Better appearance & 356 & \\
\hline & $\begin{array}{l}\text { As good as own } \\
\text { teeth during } \\
\text { function }\end{array}$ & 303 & \\
\hline \multirow{4}{*}{$\begin{array}{l}\text { What do you } \\
\text { think are the } \\
\text { disadvantages of } \\
\text { implant-supported } \\
\text { dentures/bridges? }\end{array}$} & High cost & 330 & \\
\hline & Lack of knowledge & 346 & \\
\hline & Need of surgery & 78 & \\
\hline & $\begin{array}{l}\text { Long treatment } \\
\text { time }\end{array}$ & 109 & \\
\hline
\end{tabular}

More than two-thirds of the respondents believed that fixed/nonremovable prosthesis will be "more comfortable in the mouth" and have a "better appearance." For majority of the respondents, "high costs" and "lack of knowledge" were barriers to using implant-supported dentures/bridges (Table 3). 


\section{DISCUSSION}

This study was conducted to assess the awareness and knowledge of implant-related prosthesis among the patients reporting to an outreach center. It was observed that the majority of the respondents who had heard about the implants belonged to the 16 to 40 years age group and had completed college or a higher level of education. This trend can be attributed to the interest among this age group toward advancements in dental technology. A study in Norway reported that people of 45 years and above with higher education were more aware of implants. These findings are similar to studies conducted by Saha et al, ${ }^{6}$ Kohli et al, ${ }^{7}$ and Chowdhary et al, ${ }^{8}$ where a similar trend was observed.

We found that nearly half of the study participants were aware of dental implants as a viable treatment option. These results are different than those reported by Berge ${ }^{12}$ (70.1\% awareness) and Zimmer et $\mathrm{al}^{9}(77 \%$ awareness). However, our findings are comparable to studies in the Asian context, which reported awareness levels in the range of 41.7 to $47 \%{ }^{6-8,10,13,14}$

In this study, nearly half of the respondents were moderately informed to well informed regarding the options of replacement of missing teeth. This highlights the need to increase awareness among the people regarding implant-related treatment options. On analysis of the source of information for implants, the majority reported that the dentist was the main source of information, and media was the least reported source. These findings are similar to those reported by Pommer et al, ${ }^{5}$ Chowdhary et al, ${ }^{8}$ and Kohli et al. ${ }^{7}$ This emphasizes the need to utilize media through the medium of health magazines and articles to generate awareness among the population.

Nonremovable/fixed prosthesis was rated to be more comfortable and to have better esthetics and function by the respondents. On the contrary, high cost and lack of knowledge proved to be the major barriers to seek implant treatment. Similar findings are reported in studies conducted within and outside this country. These barriers can be lowered by providing patient education with special emphasis on the point that the benefits of improved quality of life outweigh the higher cost.

\section{CONCLUSION}

This survey showed that awareness among people was low regarding the dental implants. Efforts need to be directed to increase the awareness levels by utilizing media as a tool to achieve the target. Such an effort would help people be aware preliminarily about the viable treatment options, so that additional information can be furnished at dentists' office to help them make informed decisions regarding their oral health.

\section{ACKNOWLEDGMENTS}

We are grateful to the study respondents for their cooperation.

\section{REFERENCES}

1. Aglietta M, Siciliano VI, Zwahlen M, Brägger U, Pjetursson BE, Lang NP, Salvi GE. A systematic review of the survival and complication rates of implant supported fixed dental prostheses with cantilever extensions after an observation period of at least 5 years. Clin Oral Implants Res 2009 May;20(5):441-451.

2. Alqutaibi AY. Enhancing retention of maxillary obturators using dental implants. Int J Contemp Dent Med Rev 2015; 2015:Article ID 010915.

3. Ahmed YA. Attachments used with implant supported over denture. Adv Dent Oral Health 2016;1(2):1-5.

4. Sonoyama W, Kuboki T, Okamoto S, Suzuki H, Arakawa H, Kanyama M, Yatani H, Yamashita A. Quality of life assessment in patients with implant-supported and resin-bonded fixed prosthesis for bounded edentulous spaces. Clin Oral Implants Res 2002 Aug;13(4):359-364.

5. Pommer B, Zechner W, Watzak G, Ulm C, Watzek G, Tepper G. Progress and trends in patients' mindset on dental implants. I: level of information, sources of information and need for patient information. Clin Oral Implants Res 2011 Feb;22(2):223-229.

6. Saha A, Dutta S, Vijaya V, Rajnikant N. Awareness among patients regarding implants as a treatment option for replacement of missing teeth in Chhattisgarh. J Int Oral Health 2013 Oct; 5(5):48-52.

7. Kohli S, Bhatia S, Kaur A, Rathakrishnan T. Patients awareness and attitude towards dental implants. Indian J Dent 2015 Oct-Dec;6(4):167-171.

8. Chowdhary R, Mankani N, Chandraker NK. Awareness of dental implants as a treatment choice in urban Indian populations. Int J Oral Maxillofac Implants 2010 Mar-Apr;25(2): 305-308.

9. Zimmer CM, Zimmer WM, Williams J, Liesener J. Public awareness and acceptance of dental implants. Int J Oral Maxillofac Implants 1992 Summer;7(2):228-232.

10. Satpathy A, Porwal A, Bhattacharya A, Sahu PK. Patient awareness, acceptance and perceived cost of dental implants as a treatment modality for replacement of missing teeth: a survey in Bhubaneshwar and Cuttack. Int J Public Health Dent 2011 Jan-Jun;2:1-7.

11. Lambrecht JT, Cardone E, Kühl S. Status report on dental implantology in Switzerland in 2006. A cross-sectional survey. Eur J Oral Implantol 2010 Spring;3(1):71-74.

12. Berge TI. Public awareness, information source and evaluation of oral implant treatment in Norway. Clin Oral Implants Res 2000;11(5):401-407.

13. Santhosh Kumar MP, Gayathri M. Knowledge and awareness among patients about dental implants. J Pharm Sci Res 2016;8(5):351-354.

14. Al-Fahd AA, Alsourori A, Al-Qutabi A, Farouk M, Abbas N. Impact of screw retained versus cement retained implantsupported prosthesis on peri-implantitis: a systematic review and meta-analysis. Int Dent Med J Adv Res 2015;1:1-6. 